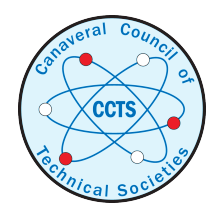

The Space Congress ${ }^{\circledR}$ Proceedings

2018 (45th) The Next Great Steps

Feb 27th, 7:30 AM - 8:30 AM

\title{
Conducting Rock Mass Rating for Tunnel Construction on Mars
}

\author{
Heidi D. Beemer \\ Chemical Defense Officer, U.S. Army \\ David Worrells \\ Embry-Riddle Aeronautical University
}

Follow this and additional works at: https://commons.erau.edu/space-congress-proceedings

\section{Scholarly Commons Citation}

Beemer, Heidi D. and Worrells, David, "Conducting Rock Mass Rating for Tunnel Construction on Mars" (2018). The Space Congress $®$ Proceedings. 9.

https://commons.erau.edu/space-congress-proceedings/proceedings-2018-45th/feb-27-2018/9

This Event is brought to you for free and open access by the Conferences at Scholarly Commons. It has been accepted for inclusion in The Space Congress ${ }^{\circledR}$

Proceedings by an authorized administrator of Scholarly Commons. For more information, please contact commons@erau.edu.

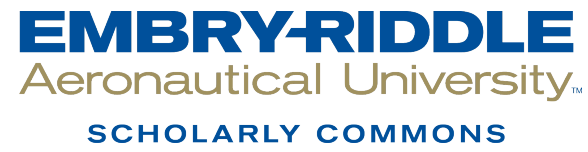
SCHOLARLY COMMONS 


\section{Conducting Rock Mass Rating for Tunnel Construction on Mars}

Heidi Beemer and David Worrells

U.S. Army

Embry Riddle Aeronautical University, Worldwide 


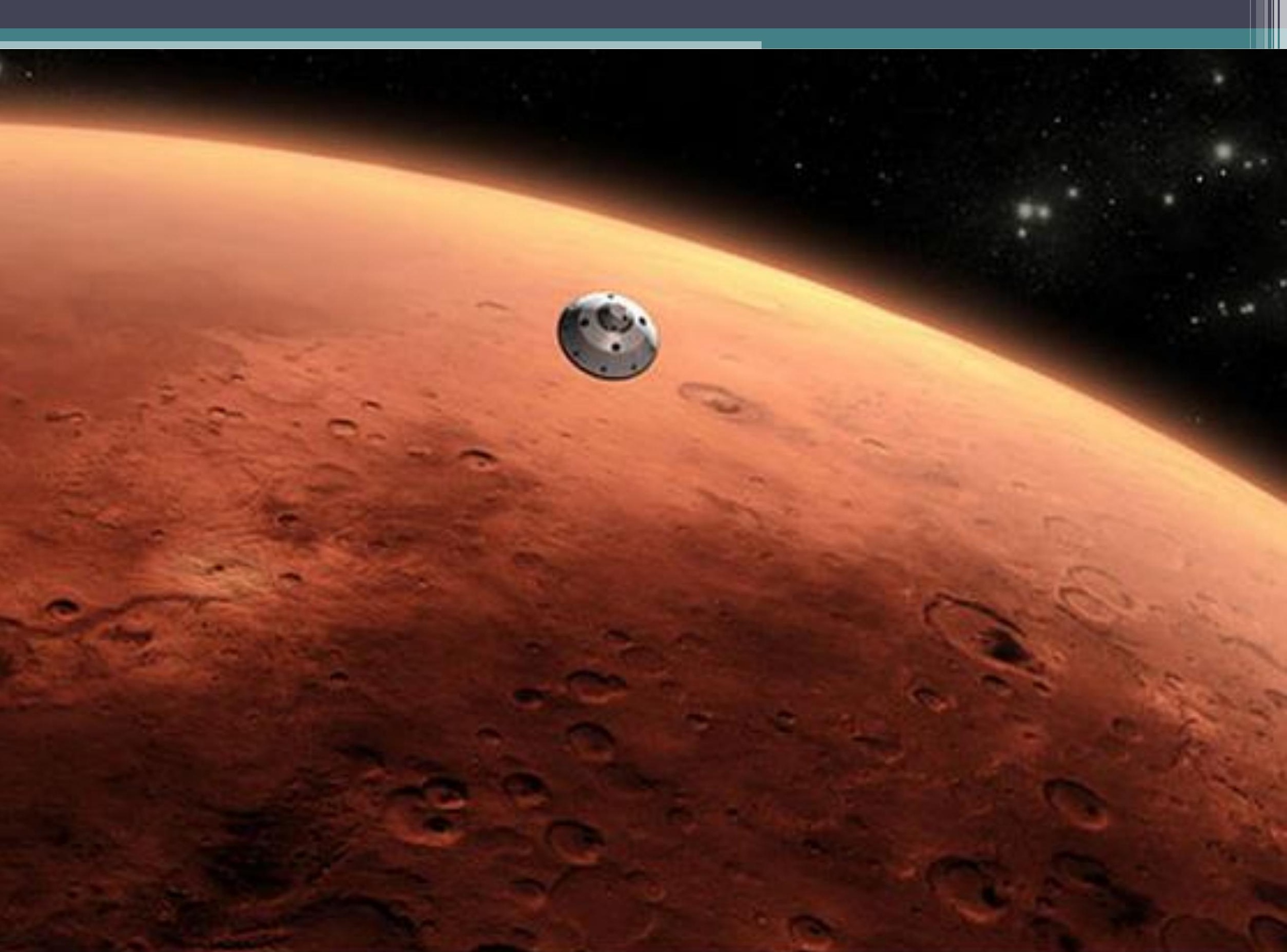




\section{Radiation on Mars}

- Radiation on Mars is a known obstacle for any mission to the red planet.

- Shielding will be the best way of mitigating its adverse effects.

\begin{tabular}{|c|c|c|c|c|c|}
\hline $\begin{array}{c}\text { Year 1 } \\
\text { (180 day transit, } 180 \text { days on } \\
\text { Mars) }\end{array}$ & \multicolumn{2}{c|}{ Year 2 } & \multicolumn{2}{c|}{ Year 3 } \\
(320 days on Mars, 40 days transit) & \multicolumn{2}{c|}{ (140 days transit to Earth) } \\
\hline $\begin{array}{c}180 \text { Transit } \\
(1.84 \pm 0.30 \\
\mathrm{mSv} / \text { day) }\end{array}$ & $331 \pm 54 \mathrm{mSv}$ & $\begin{array}{c}320 \text { days on } \\
\text { Mars }(0.64 \pm 0.12)\end{array}$ & $205 \pm 38 \mathrm{mSv}$ & $\begin{array}{c}140 \text { Transit } \\
(1.84 \pm 0.30 \\
\mathrm{mSv} / \text { day })\end{array}$ & $258 \pm 42 \mathrm{mSv}$ \\
\hline $\begin{array}{c}180 \text { days on } \\
\text { Mars } \\
(0.64 \pm 0.12)\end{array}$ & $169 \pm 22 \mathrm{mSv}$ & $\begin{array}{c}40 \text { Transit }(1.84 \pm \\
0.30 \mathrm{mSv} / \text { day) }\end{array}$ & $73.6 \pm 12 \mathrm{mSv}$ & $\begin{array}{c}220 \text { days on } \\
\text { Earth }\end{array}$ & negligible \\
\hline Total mSv & $500 \pm 76$ & Total mSv & $\begin{array}{c}279 \pm 50 \\
\mathrm{mSv} / \text { year }\end{array}$ & Total mSv & $\begin{array}{c}258 \pm 42 \\
\mathrm{mSv} / \text { year }\end{array}$ \\
\hline Total Rem & $\begin{array}{c}50.0 \pm 7.6 \\
\text { Rem/year }\end{array}$ & Total Rem & $\begin{array}{c}27.9 \pm 5.0 \\
\text { Rem/year }\end{array}$ & Total Rem & $\begin{array}{c}25.8 \pm 4.2 \\
\text { Rem/year }\end{array}$ \\
\hline
\end{tabular}




\section{Living in the Lander}
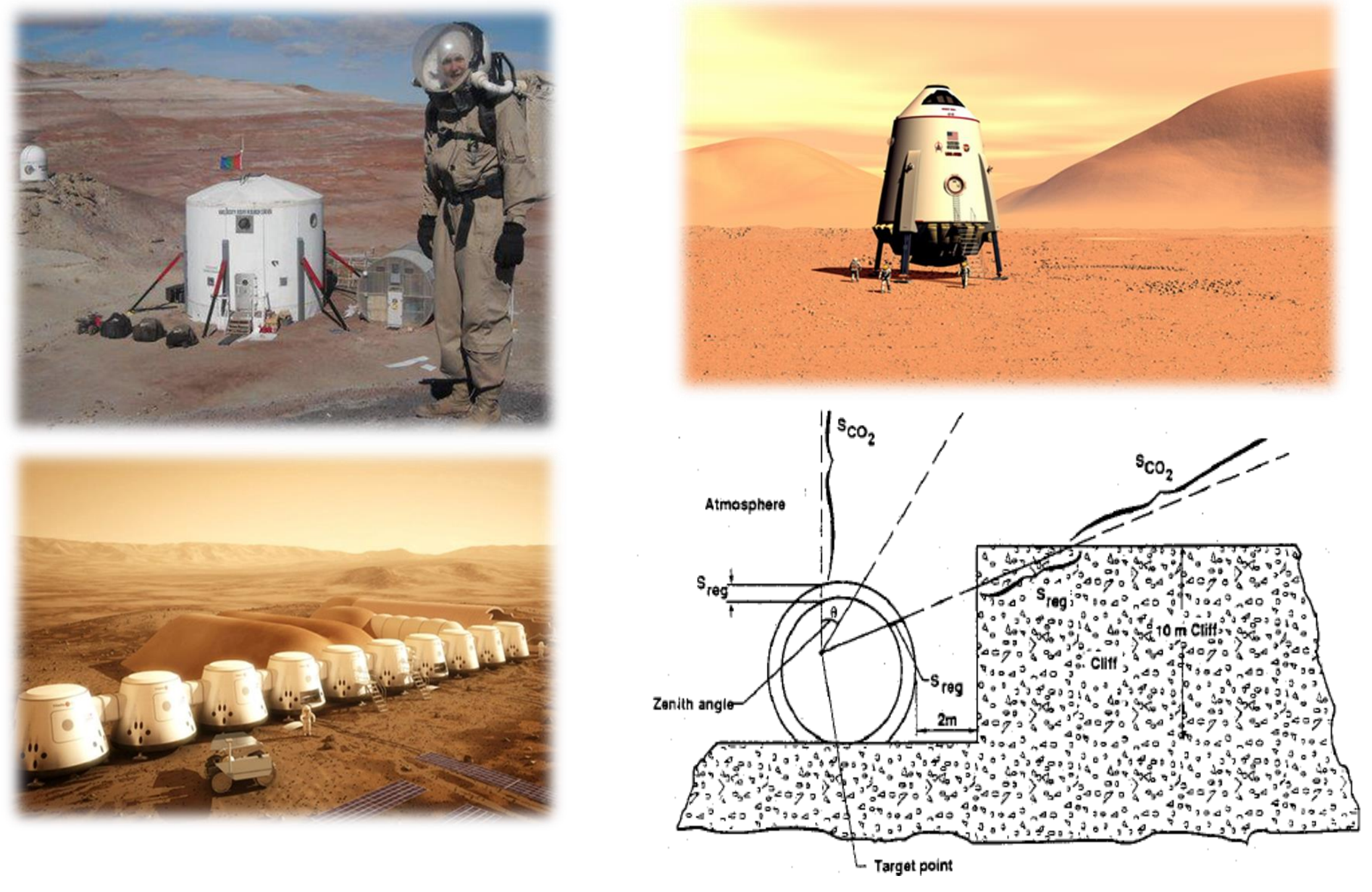


\section{A More Permanent Solution}

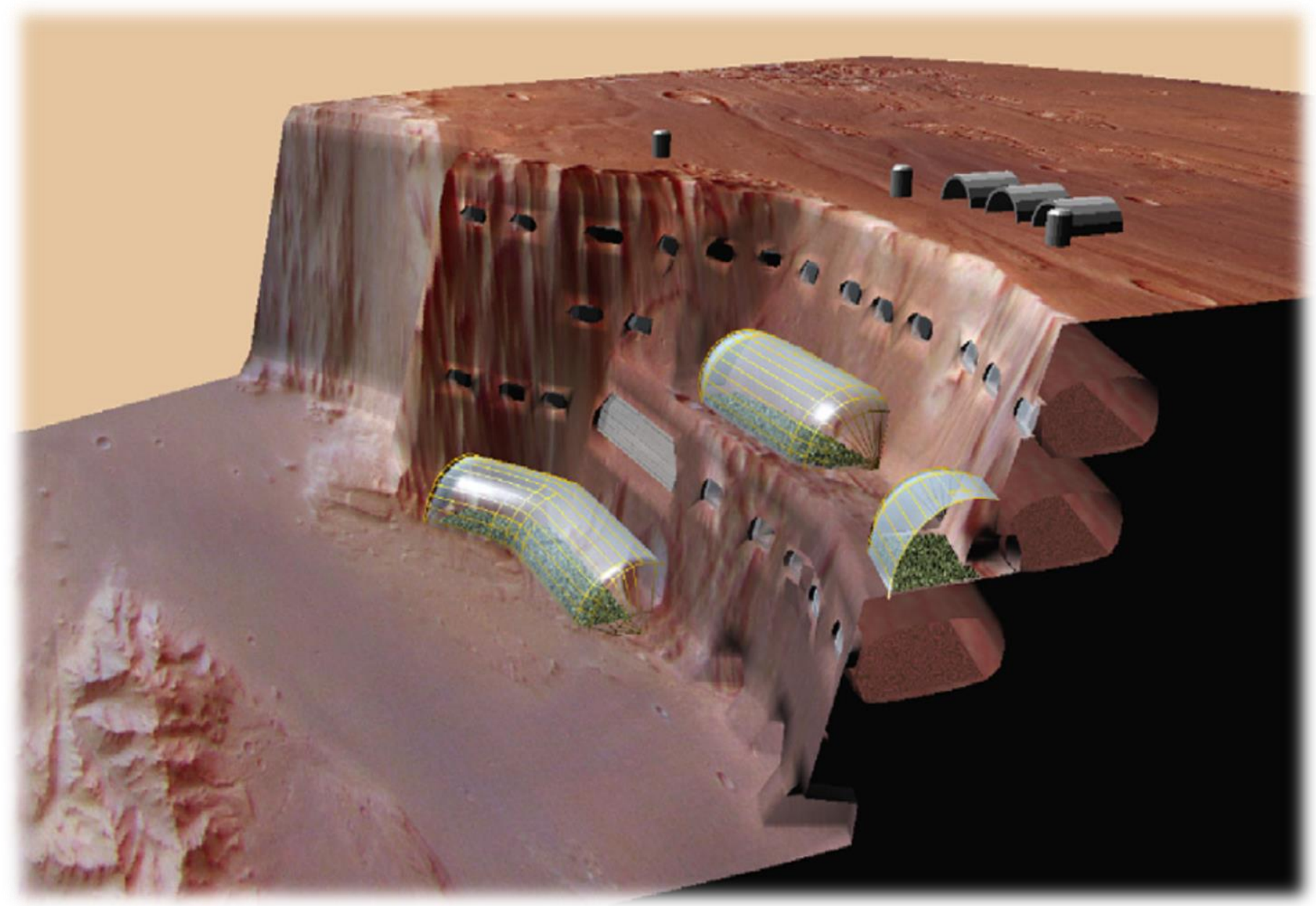


How do we get from landers to tunnels for long term colonization of Mars?

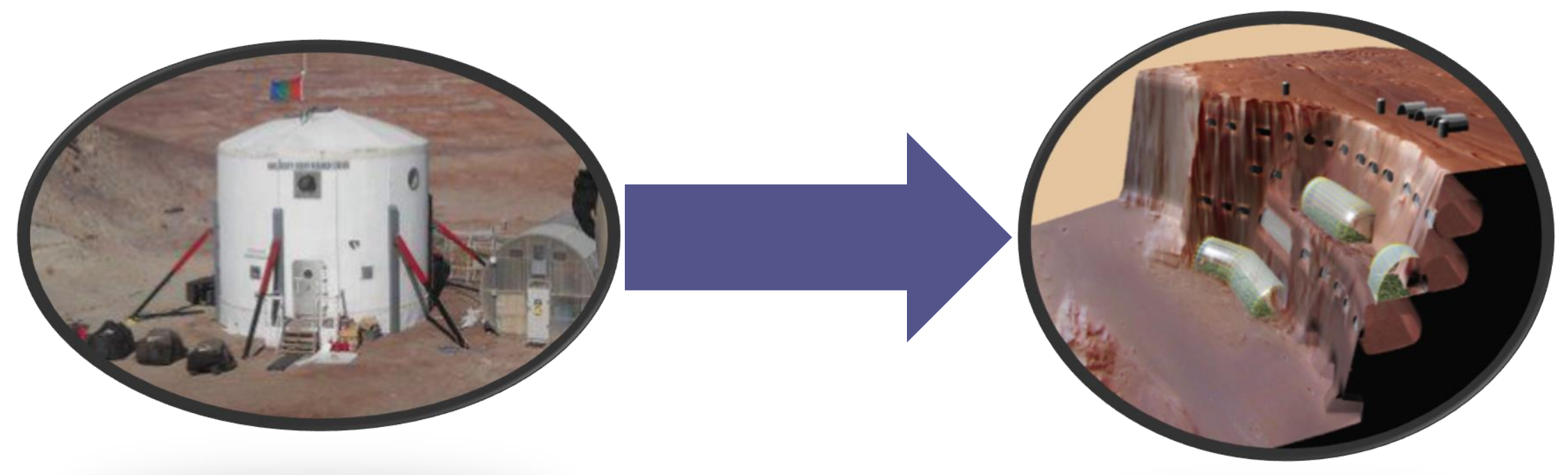




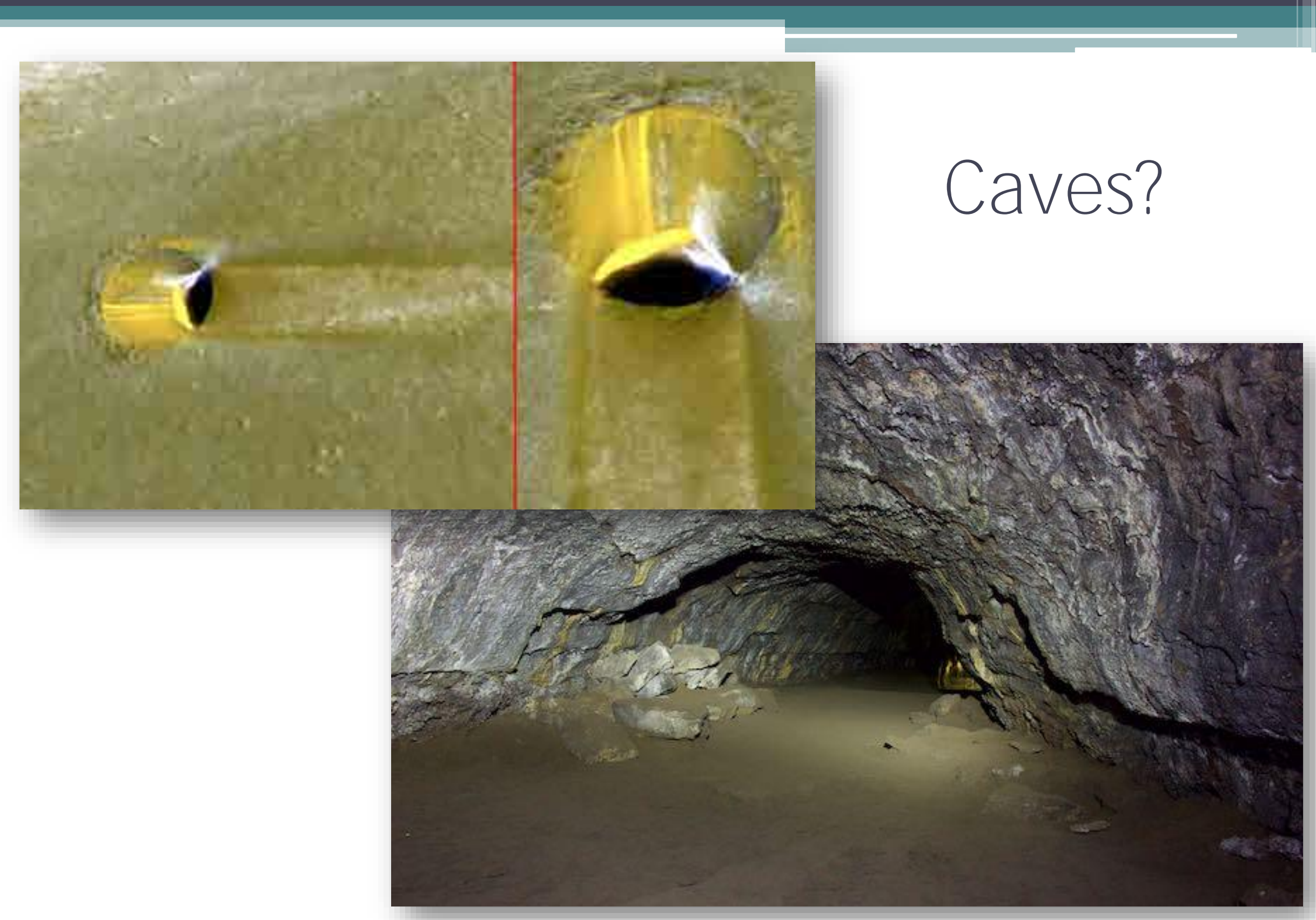




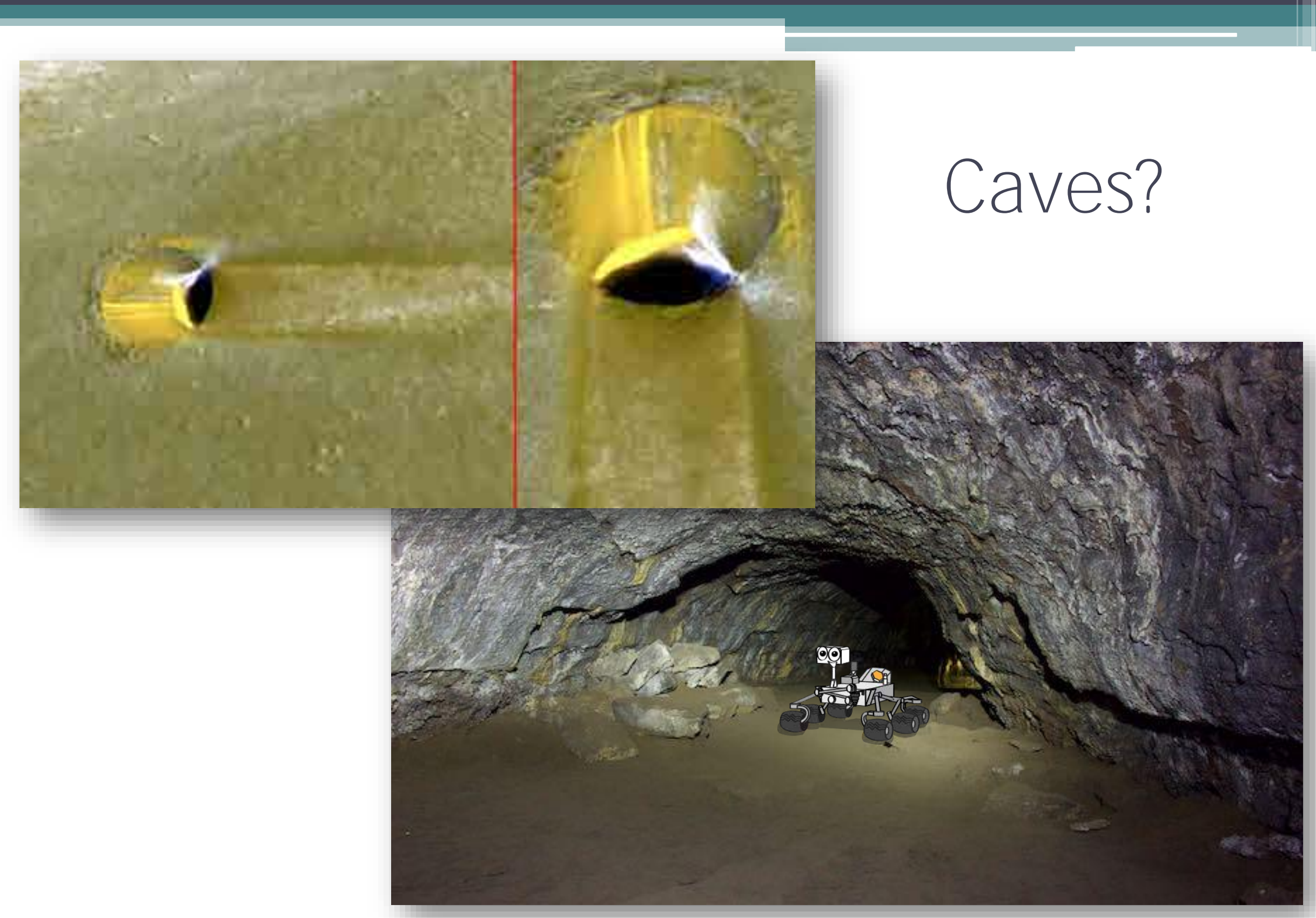




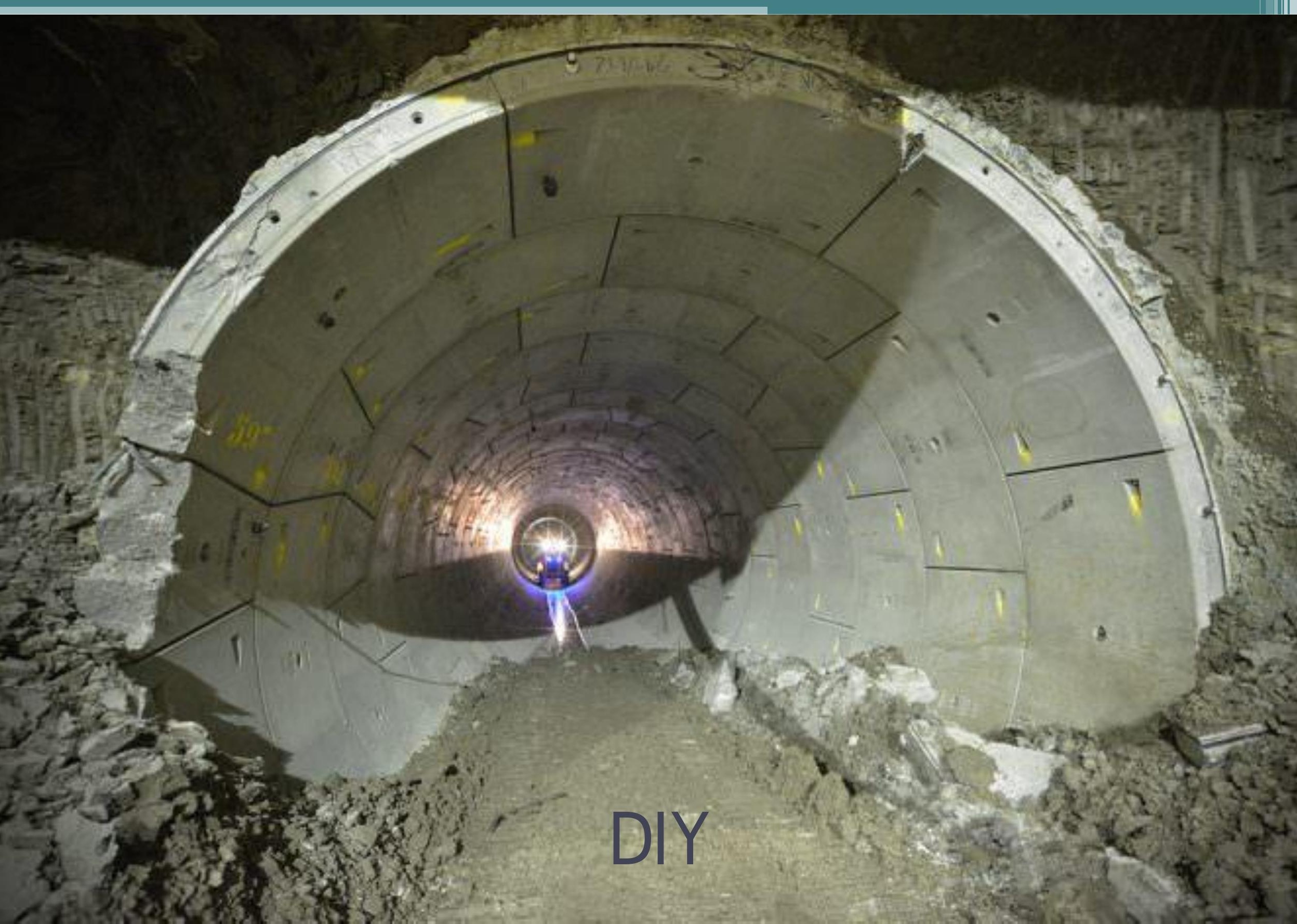



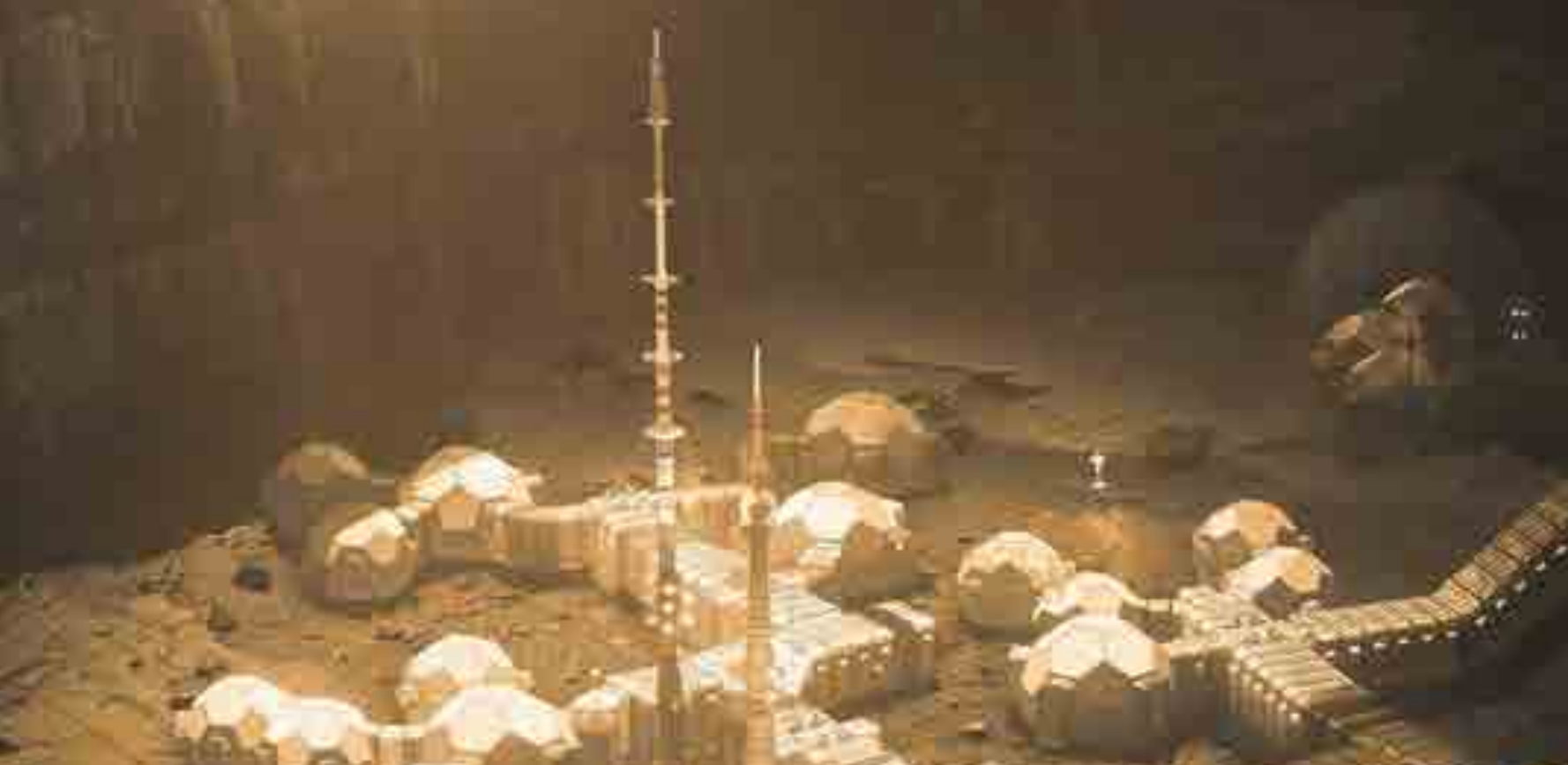

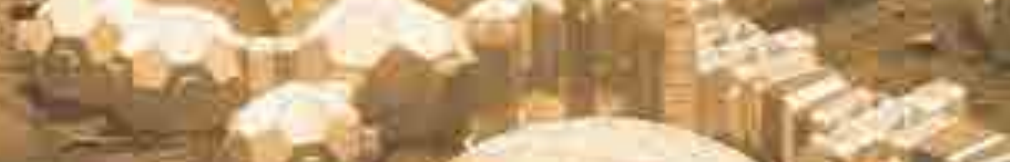

$\operatorname{lin}_{3}$

wes? 2835

-

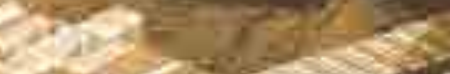

40

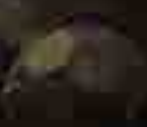

(2) 9.5

4. \& or the

$=$

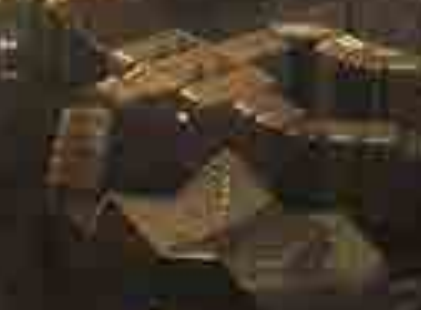

W

$\triangle$

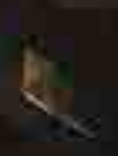

4.

8

$s$ 


\section{Rock Mass Rating}

- According to Z.T. Bieniawski (1979) RMR is the easiest way to classify the geomechanics of a site.

- Primarily used for tunneling projects, but can also be applied to slopes, foundations, and mines.

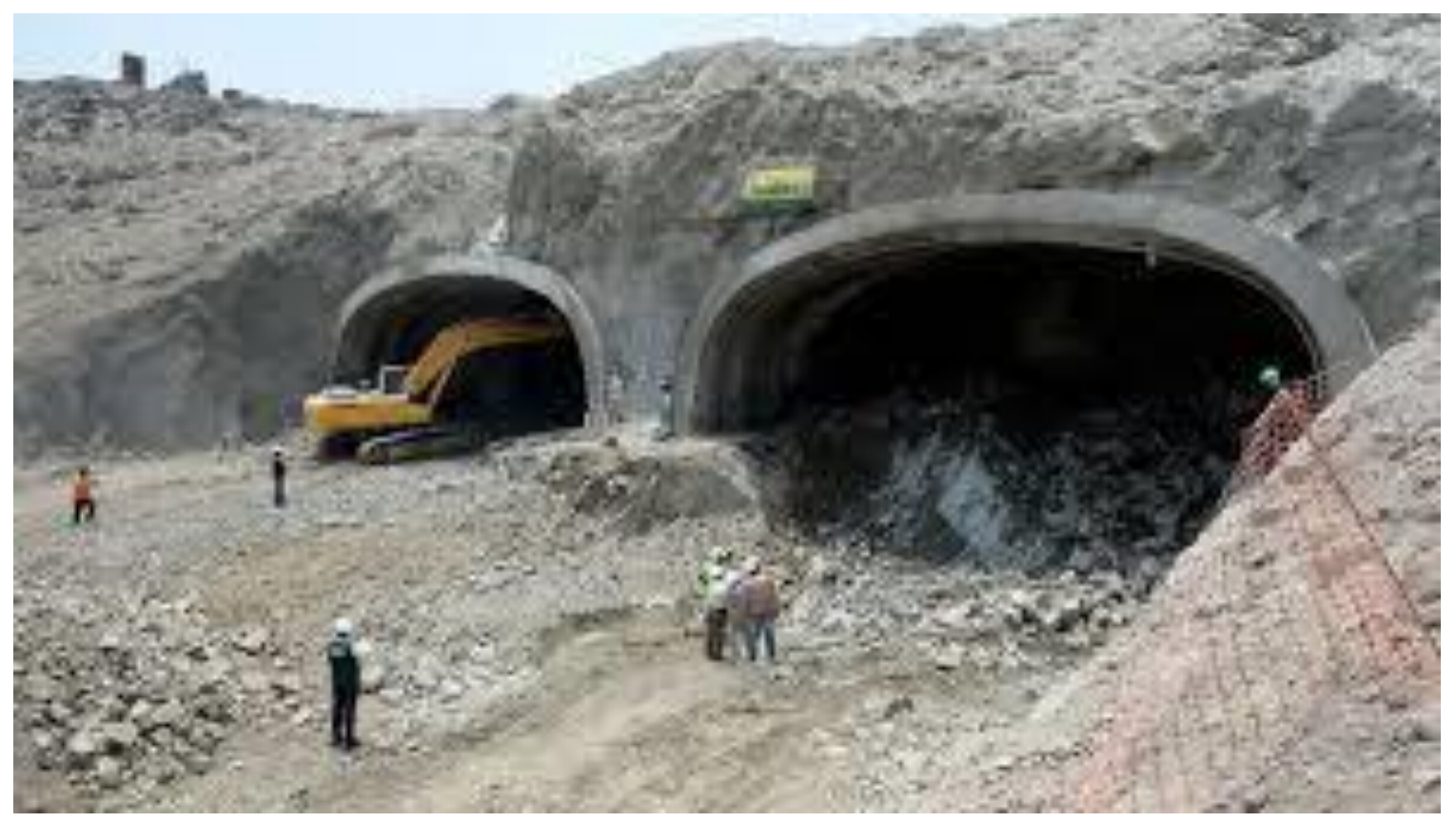




\section{Rock Mass Rating}

- Aims of the RMR System:

1. Identify the most significant parameters influencing the behavior of a rock mass.

2. Divide a particular rock mass formation into a number of rock mass classes of varying quality.

3. Provide a basis for understanding for engineering design

4. Derive quantitative design for engineering design

5. Provide a common basis for communication between engineers and geologists. 


\section{Rock Mass Rating cont.}

- Rating uses six parameters to classify rock formations:

- Uniaxial compressive strength of rock material

- Rock Quality Designation (RQD)

- Spacing of

Discontinuities

- Condition of Discontinuities

- Ground Water Conditions

\begin{tabular}{|c|c|c|c|c|c|c|c|c|c|}
\hline \multicolumn{10}{|c|}{ 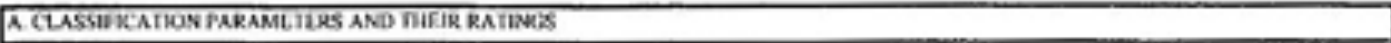 } \\
\hline \multicolumn{3}{|r|}{ Paranuser } & \multicolumn{7}{|c|}{ Raspe of vilues } \\
\hline & \multirow{2}{*}{ 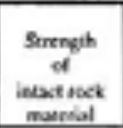 } & \multirow{2}{*}{ 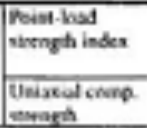 } & \multirow{2}{*}{ 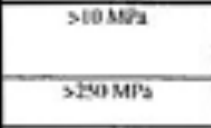 } & \multirow{2}{*}{ 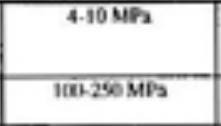 } & \multirow{2}{*}{$\begin{array}{c}2-4 \mathrm{MPz} \\
50-1001 \mathrm{MPz}\end{array}$} & \multirow{2}{*}{$\begin{array}{l}1.2 \mathrm{MPa} \\
25.50 \mathrm{Mh}\end{array}$} & \multicolumn{3}{|c|}{ 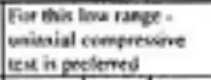 } \\
\hline 1 & & & & & & & $\begin{array}{l}5.25 \\
\text { Mra }\end{array}$ & $\begin{array}{c}1.5 \\
\text { MFs }\end{array}$ & $\begin{array}{ll}1 \\
\text { Mis }\end{array}$ \\
\hline & \multicolumn{2}{|r|}{ Kaing } & 15 & 12 & $T$ & 4 & $\frac{2}{2}$ & $T$ & 0 \\
\hline \multirow[b]{2}{*}{2} & \multicolumn{2}{|c|}{ Drili coese Qualing ago } & क्रh-1006 & 75क्ष्पर्ज & $500-752$ & $25 \pi-54$ & \multicolumn{3}{|c|}{$<297$} \\
\hline & \multicolumn{2}{|r|}{ Exing } & 20 & 17 & 13 & $\pi$ & & 3 & \\
\hline \multirow[b]{2}{*}{3} & \multicolumn{2}{|c|}{ Spacing of thecentinsities } & $>2 \mathrm{~m}$ & $0,0-2=m$ & $200-600 \pi m$ & $60.200 \mathrm{~mm}$ & \multicolumn{3}{|c|}{ <6 mm } \\
\hline & \multicolumn{2}{|r|}{ Rwing } & 20 & is & 10 & 8 & \multicolumn{3}{|c|}{5} \\
\hline 4 & \multicolumn{2}{|c|}{$\begin{array}{l}\text { Condaieseof dscusinuties } \\
\text { (See E) }\end{array}$} & 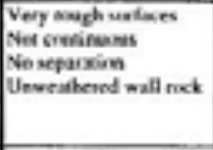 & 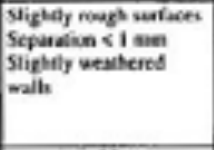 & 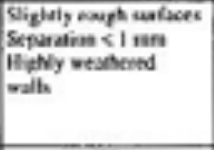 & 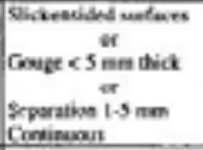 & \multicolumn{3}{|c|}{ 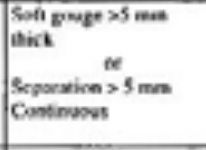 } \\
\hline & \multicolumn{2}{|r|}{ kising } & 30 & 23 & 5 & 10 & \multicolumn{3}{|c|}{0} \\
\hline \multirow{4}{*}{5} & \multirow{4}{*}{$\begin{array}{c}\text { Conond } \\
\text { waler }\end{array}$} & 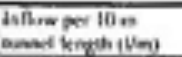 & Nase & $<10$ & 10.25 & 25.125 & \multicolumn{3}{|c|}{$>125$} \\
\hline & & 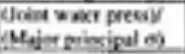 & 0 & $\mathrm{cel}$ & $0.1,02$ & 0.205 & \multicolumn{3}{|c|}{305} \\
\hline & & \multirow{2}{*}{ Gerwad ceostimas } & cheseverty is & $\tan x$ & $\overline{\nabla e}$ & Dritios & \multirow{2}{*}{\multicolumn{3}{|c|}{ Phaie }} \\
\hline & & & is & 10 & 7 & 4 & & & \\
\hline \multicolumn{10}{|c|}{ 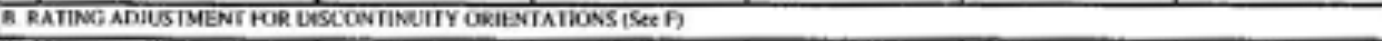 } \\
\hline & ic and dip & ericktaions & very tamerible & Frovorbile & $m$ & Uniawentht & Very & Undawer & roble \\
\hline & & Tumsh $A$ mifes & $\theta$ & 2 & 5 & $=10$ & & -12 & \\
\hline & Iarisess & Foveditims & 0 & 2 & 7 & -15 & & 25 & \\
\hline & & Sheves & 0 & 5 & 28 & 50 & & & \\
\hline
\end{tabular}

- Orientation of

Discontinuities 


\section{Rock Mass Rating (cont)}

- Each parameter is given a number rating based on present conditions.

- Final RMR is a number 1-100 totaling previous ratings.

- Rating allows the engineer to know the behavior of the rock.

- Providing quantitative data for engineering design.

\begin{tabular}{|l}
\begin{tabular}{|l|c|c|c|c|c|}
\hline C. ROCK MASS CI.ASSES DEITERMINED FROM TOTAL RATINGS & \\
\hline Rating & $100 \leftarrow 81$ & $80 \leftarrow 61$ & $60 \leftarrow 41$ & $40 \leftarrow 21$ & $<21$ \\
\hline Class number & $\mathrm{l}$ & II & III & IV & V \\
\hline Description & Very gond rixk & Good ruck & Fair rock & Poor ronk & Very ponr rock \\
\hline
\end{tabular}
\end{tabular}




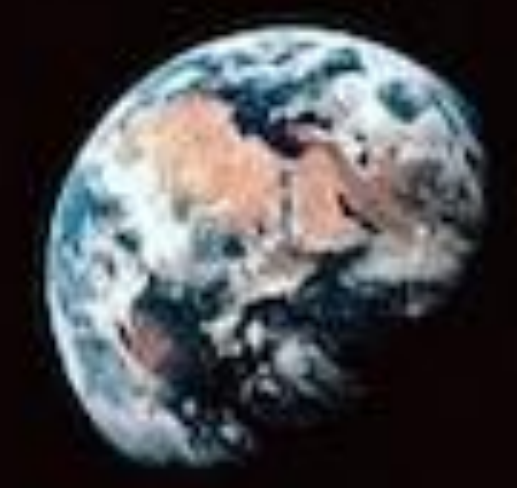

How do we bring

this Earth based engineering to Mars? 


\section{Identifying Rock Structures}

- Remote sensing techniques may be used to initially determine feasible sites for tunnel construction before committing a Martian colony to one site.

- Nahm and Schultz (2007) conducted a remote RMR for a Martian outcrop located within Vostok crater at Meridiani planum, Mars, using Remote sensing instruments

- NASA's Mars Orbiter Camera (MOC)

- Opportunity's navigation camera

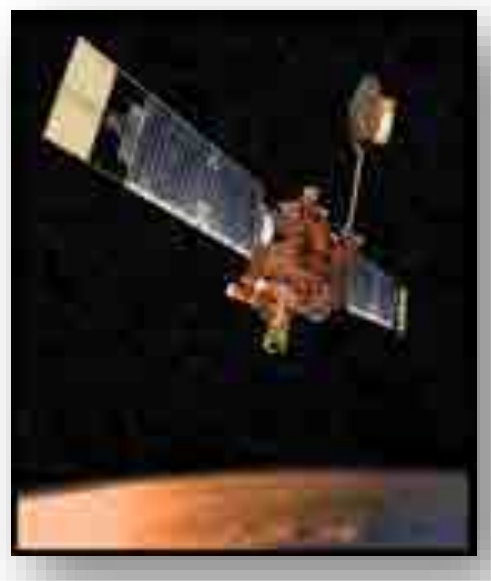
(NAVcam)

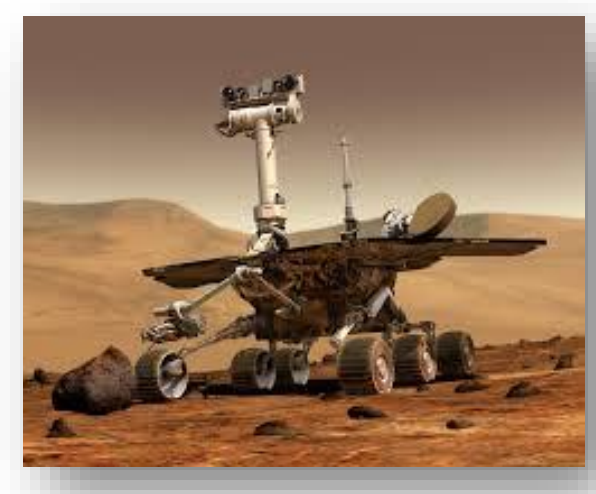




\section{Identifying Rock Structures}

- Once on the ground, Astronauts will be able to confirm RMR results remotely calculated. 


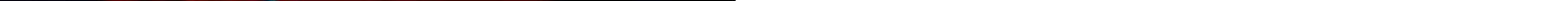




\section{$2 \pi$ \\ MARS DESERT RESEARCH STATION}

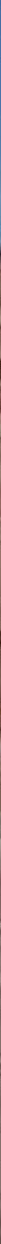




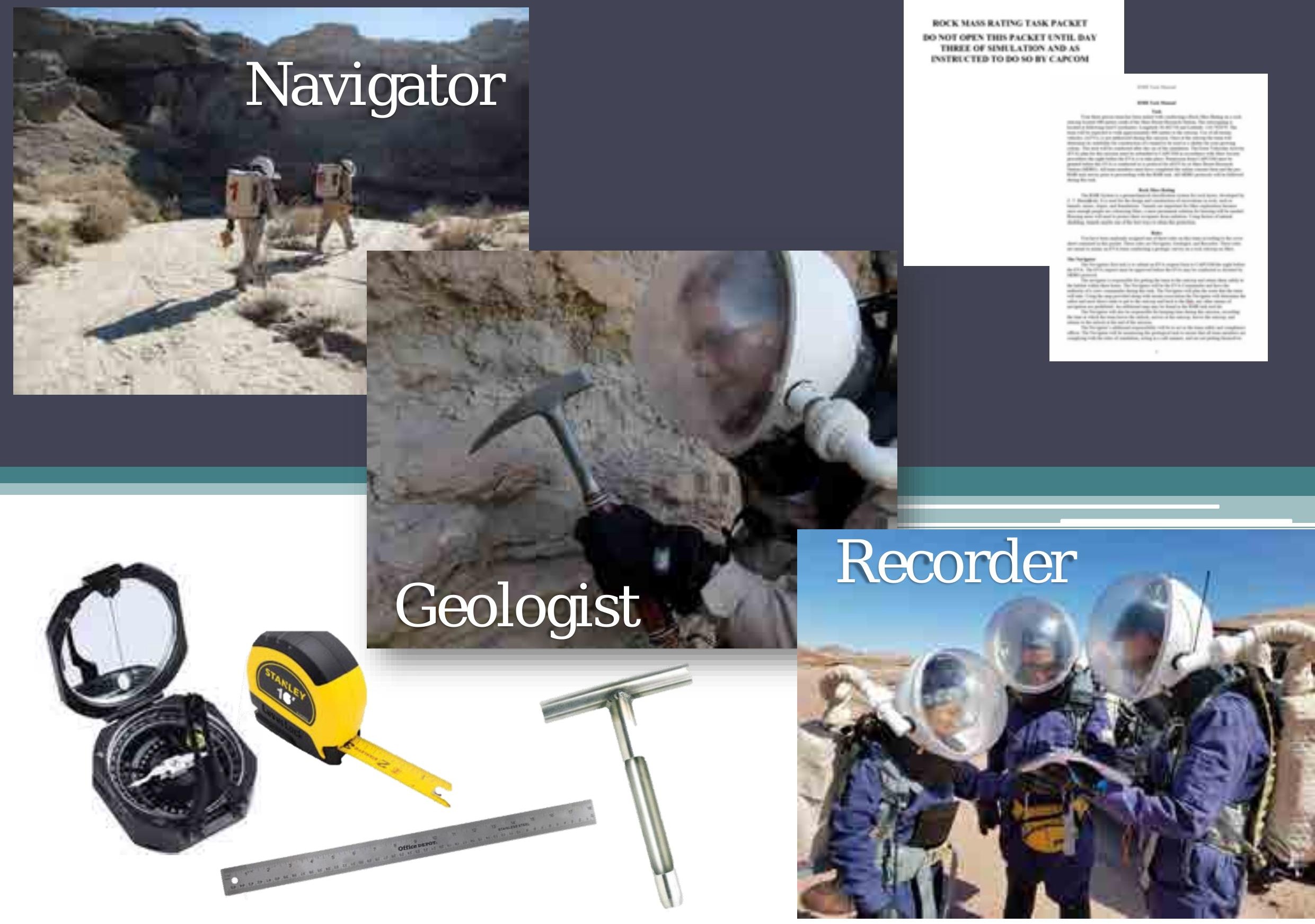




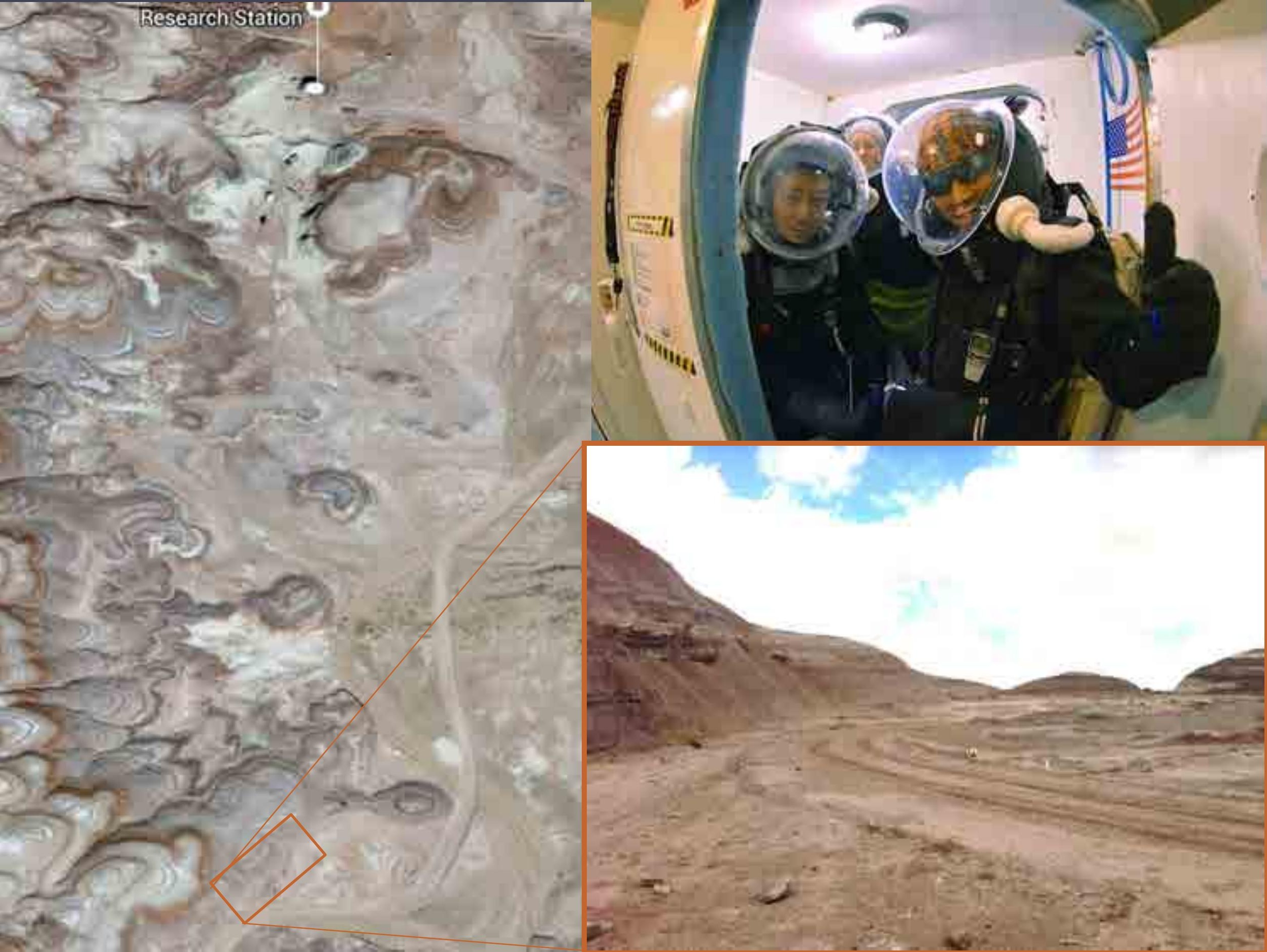


- Location: Longitude 38.402738 and Latitude -110.792079

- RMR 63

- Classification: Good Rock

\begin{tabular}{|c|c|c|}
\hline Geomechanics Classification & Result & \# Rating \\
\hline Drill Core Quality R.Q.D & Fair Quality 50-75\% & 13 \\
\hline Wall Rock of Discontinuities & Moderately weathered & 20 \\
\hline Ground Water & Completely Dry & 15 \\
\hline Strength of Intact Rock Material & Med High 50-100 MPa & 7 \\
\hline Spacing of Discontinuities & Wide (200-600 mm) & 10 \\
\hline Strike and Dip Orientations & Favorable & -2 \\
\hline
\end{tabular}




\section{Results}

The task was complete in less than three hours

$\underline{\text { Maximum Points per Task }}$

20

The team was able to locate the rock outcrop

$\underline{\text { Rock Mass Rating Geologic Tasks }}$

1. Uniaxial compressive strength of rock material

2. Rock quality designation

3. Spacing discontinuities

4. Condition of discontinuities

5. Ground water conditions

6. Orientation of discontinuities

Completed the task safely

Correctly calculated RMR number using tables provided 20 


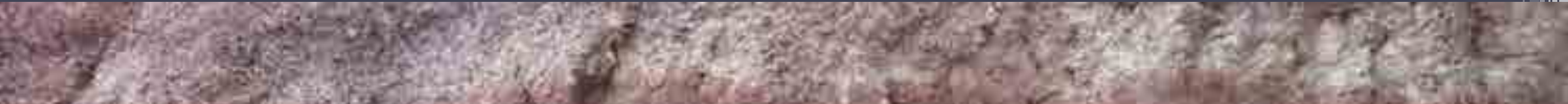

F. (3) 4.

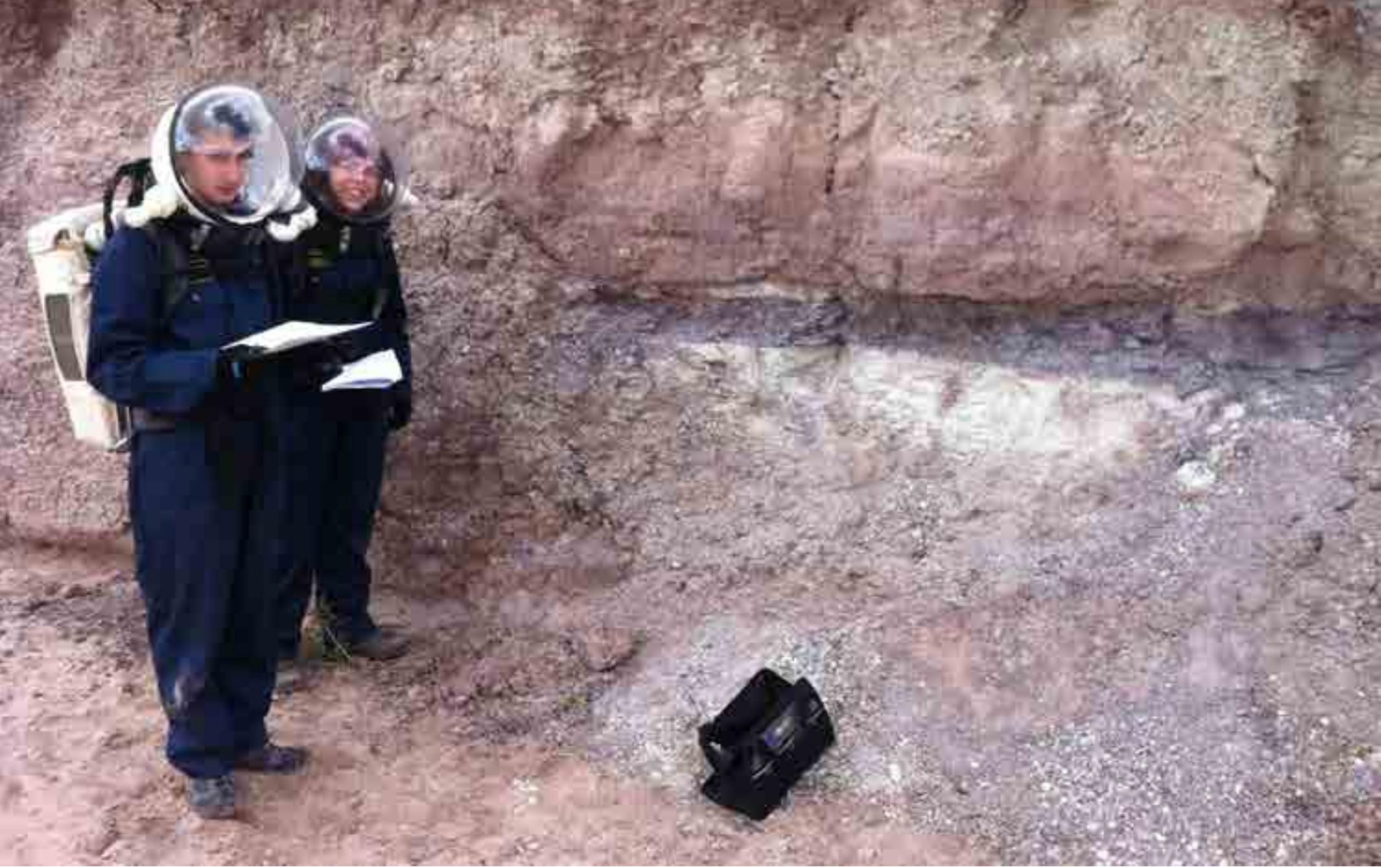




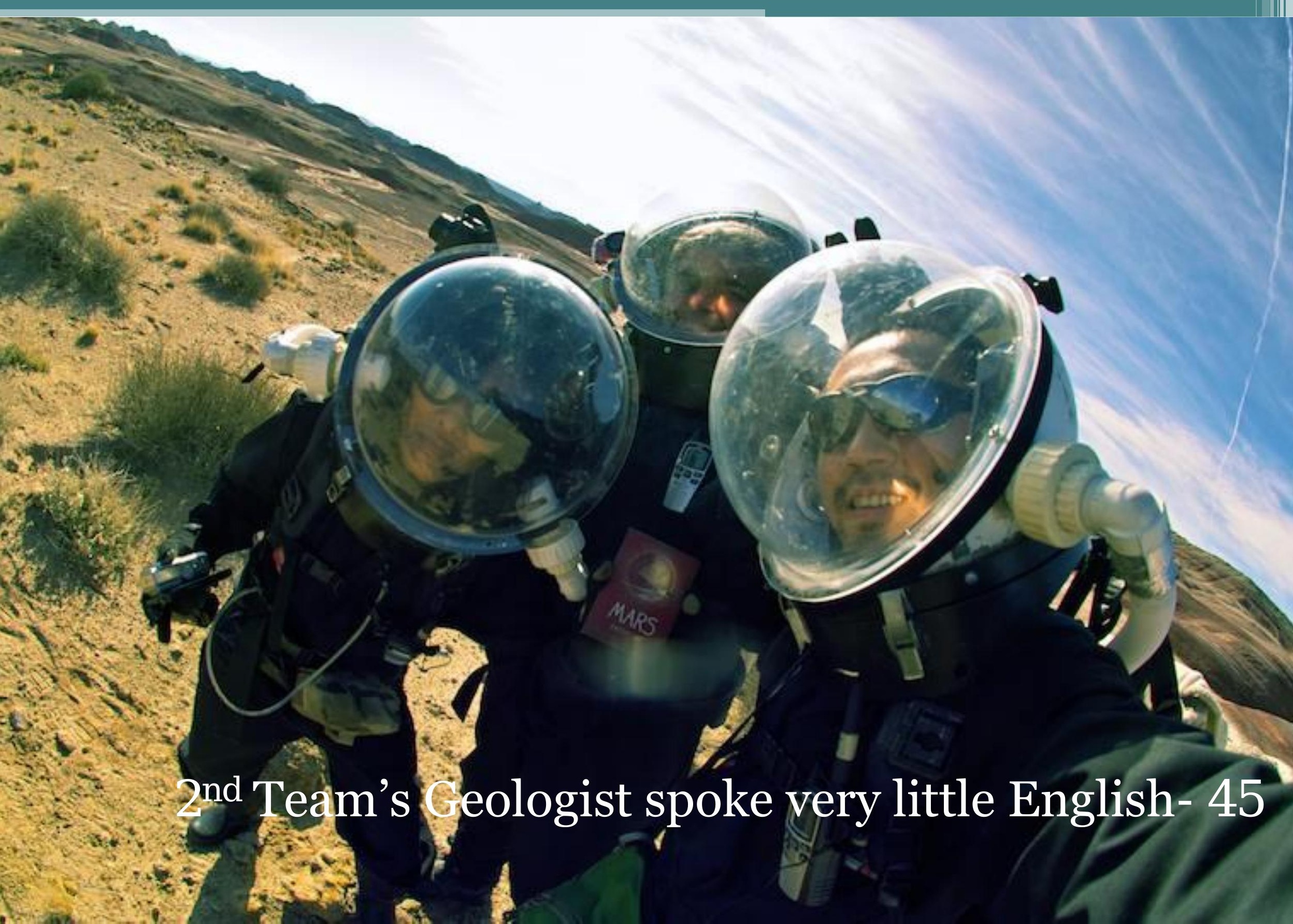




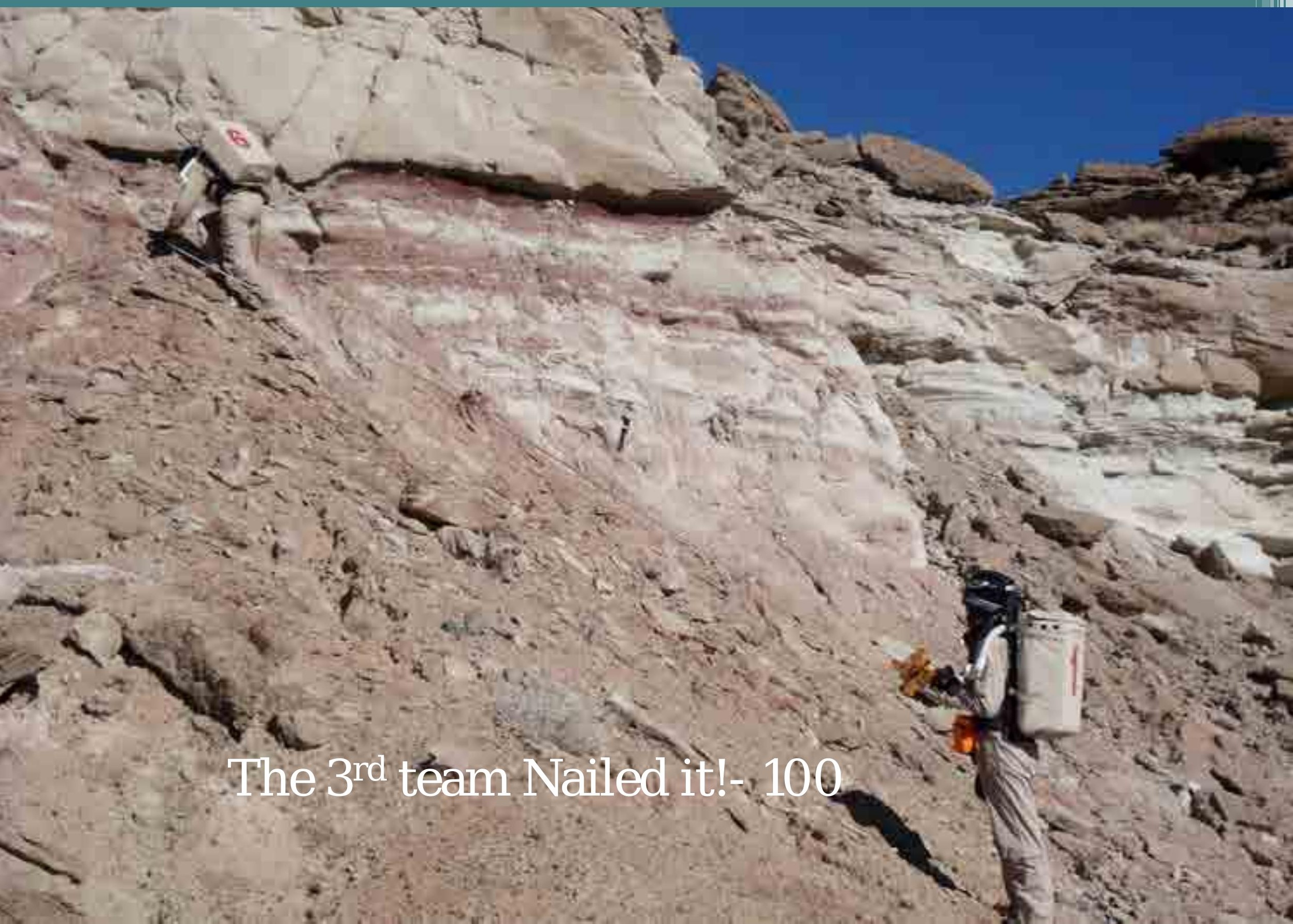




\section{Results}

Crew Number

167

168

169

100

\section{Task Performance}

\begin{tabular}{cccc}
\cline { 1 - 1 } Mean & Standard Deviation & & Range \\
76.67 & 24.62 & & $45-100$ \\
\hline
\end{tabular}

Note. $\mathrm{N}=9$. 


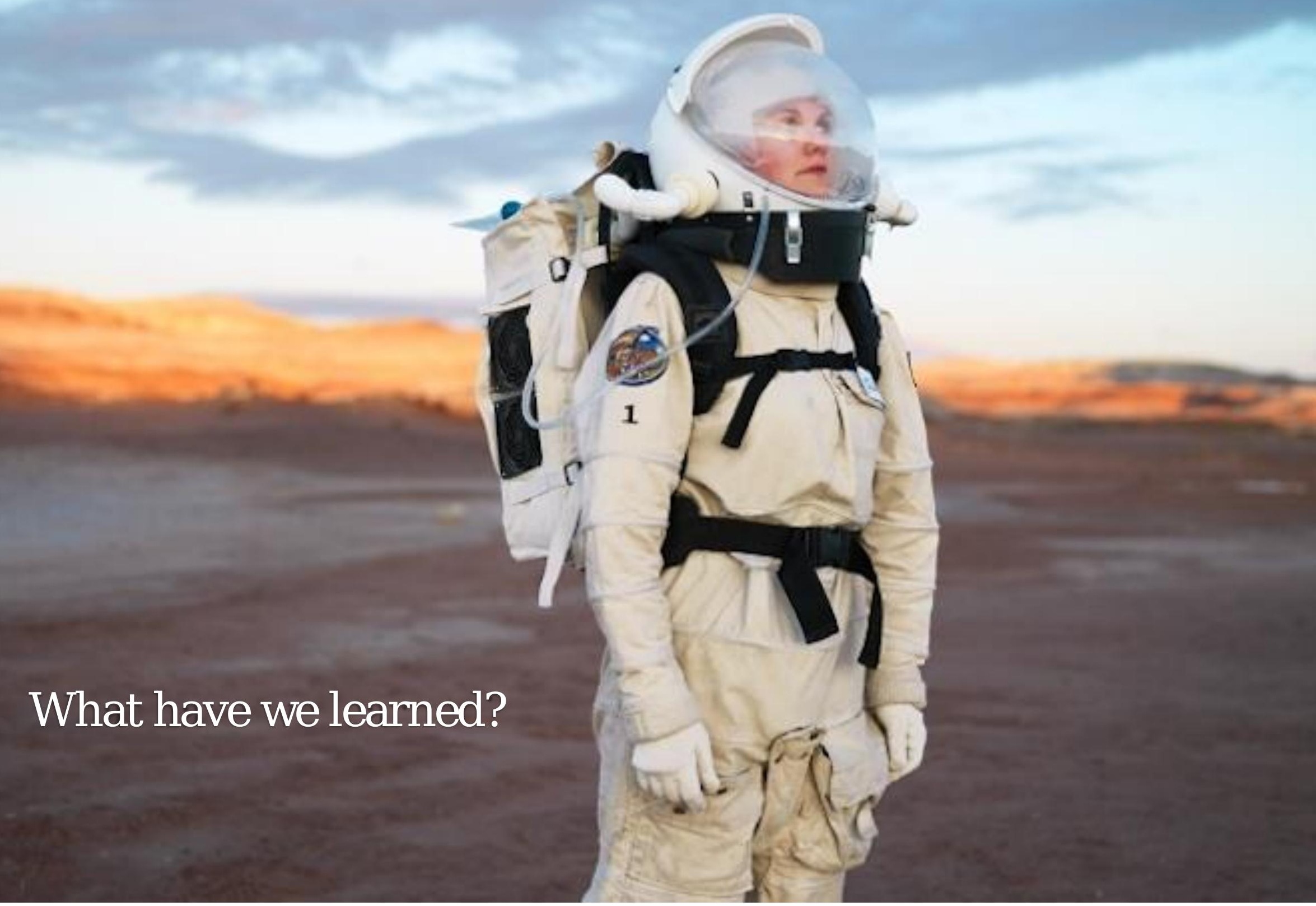




\section{Conclusions}

- It can be concluded that the task of determining the Rock Mass Rating of a rock structure can be conducted by a Martian Simulation Astronaut.

- Without an engineering back ground, astronauts can collect the data needed for engineers back on earth to design a plan for a future Martian shelter.

- The more knowledge and practice the team had on Geological survey techniques, the better the results.

- To replicate on Mars, teams would require additional core sample equipment. 


\section{Recommendations}

- Reevaluating the task manual and include training prior to task performance

- Determine participants geological survey knowledge prior to task completion to determine effectiveness of training.

- Continue to analyze the human factors that effect performance

- Team Efficacy

- Stress

- Feeling of isolation 


\section{References}

Bieniawski, Z. T. (1988). The rock mass rating (RMR) system (geomechanics classification) in engineering practice. In L. Kirkaldie (Ed.), Rock classification systens for engineering purposes (pp. 17-17-34). Ann Arbor, MI: American Society For Testing And Materials.

Hamidi, J . K., Shahriar, K., Rezai, B., \& Rostami, J . (2010). Preformance prediction of hard rock TBM using rock mass rating (RMR) system. Tunnelling and Underground Space Technology, 25(4), 333-345.

doi:http:// dx.doi.org.ezproxy.libproxy.db.erau.edu/10.1016/j.tust.2010.01.008

Hassler, D. M., Zeitlin, C., Wimmer-Schweingruber, R. F., Ehresmann, B., Rafkin, S., Eigenbrode, J . L., et al. (2014). Mars' surface radiation environment measures with the mars science laboratory's curiosity rover. Science, 343, 1244797-1-6.

Kozicka, J . (2008). Low-cost solutions for Martian base. Advances in Space Research, 41(1), 129-137.

Simonsen, L. C., Nealy, J. E., Townsend, L. W., \&Wilson, J. W. (1991). Martian regolith as space radiation shielding. J ournal of Spacecraft and Rockets, 28(1), 7-8.

Photos credited to:

Space.com; Nat Geo; Mars Society; NASA 


\section{Questions?}

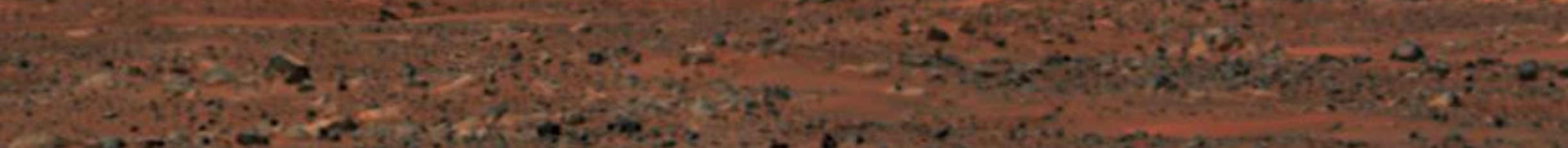

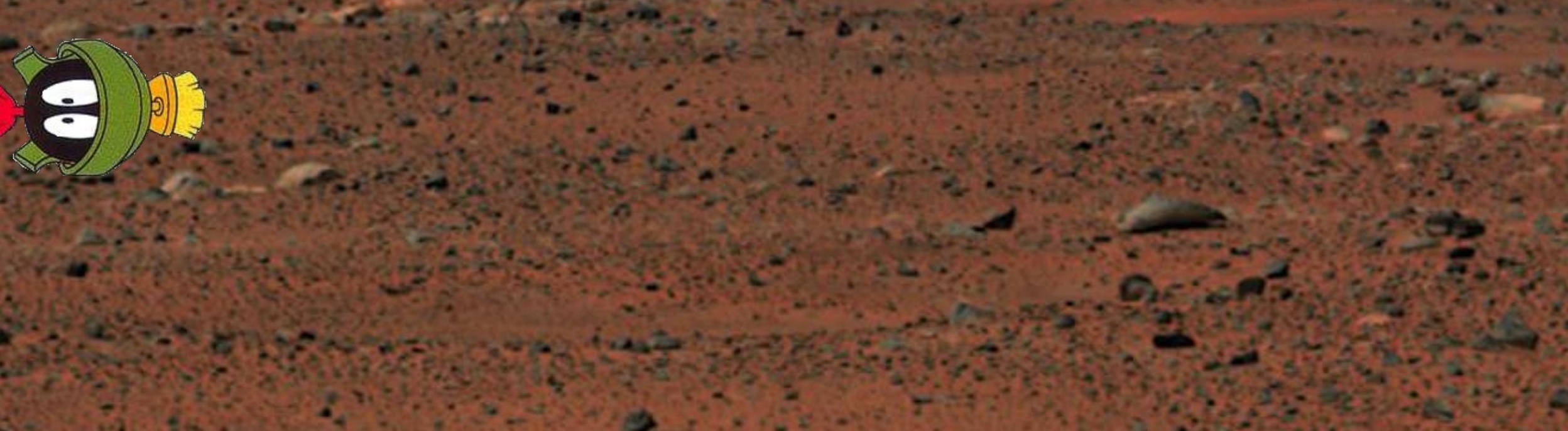

